\title{
Solidarity in diversity: online petitions and collective identity in Hong Kong's Anti-Extradition Bill Movement
}

\author{
Samson Yuen ${ }^{\star}$ (D) and Kin-long Tong ${ }^{2}$ \\ ${ }^{1}$ Hong Kong Baptist University, Kowloon Tong, Hong Kong and ${ }^{2}$ University College London, London, UK \\ ${ }^{*}$ Corresponding author. E-mail: samsonyuen@hkbu.edu.hk
}

(Received 17 March 2021; revised 12 July 2021; accepted 20 September 2021; first published online 2 December 2021)

\begin{abstract}
Collective identity is a key catalyst of protest mobilization. How does collective identity come into existence among strangers with diverse backgrounds, especially in movements without a centralized leadership? Although collective identity is often seen as something constructed by movement organizations or out of established networks, we describe a more bottom-up and decentralized process in which movement collective identity is created through the horizontal mobilization of intermediate identities, which leverage pre-existing social identifications to induce commitment among individuals. Focusing on Hong Kong's Anti-Extradition Bill Movement of 2019, we argue that online petitions against the controversial bill created intermediate group identities among myriad social groups, such as alumni, professions, hobby groups, and residential communities. These intermediate identities provided rich discursive resources for previously disconnected individuals to collectively perceive the threat of the bill and see the obligation to act, which, in turn, shaped a strong collective identity early on in the protests. Our findings may help contribute to a more nuanced understanding of collective identity formation in contemporary leaderless movements.
\end{abstract}

Key words: Collective identity; Hong Kong; petitions; protests; social identity

\section{Introduction}

In late May 2019, shortly before a protracted wave of protests that would pervade Hong Kong for the rest of the year, a silent mobilization gained momentum on the Internet. Hundreds of online petitions were circulated on different social media platforms to oppose the highly disputed amendment to the city's extradition law, which would allow for the transfer of legal suspects to neighboring mainland China. The petition campaign started with the city's secondary schools and universities. Alumni, students, and teachers from different schools drafted and signed their statements, drawing upon their schools' symbols and moral edicts to frame their opposition against the bill. It then spread to different professions: lawyers, bankers, accountants, journalists, doctors, nurses, and tech workers all published their petitions. Parents, housewives, immigrants, churches, residential communities, and myriad hobby groups followed suit. By early June, over 400 petitions were already circulating on various social media platforms.

The petition campaign foreshadowed the ensuing street mobilizations that would put Hong Kong under the global limelight. On 9 June, 1 million people took part in a peaceful march in opposition to the extradition bill, making this the largest protest after Hong Kong's sovereignty handover. Although the government decided to suspend the bill on 15 June, 2 million people marched again on the following day to demand its complete withdrawal. New demands were added, including an independent investigation into police brutalities, the immediate release of all arrestees, the dropping of the riot

(c) The Author(s), 2021. Published by Cambridge University Press. This is an Open Access article, distributed under the terms of the Creative Commons Attribution licence (http://creativecommons.org/licenses/by/4.0/), which permits unrestricted re-use, distribution and reproduction, provided the original article is properly cited. 
characterization, and a timetable for political reforms. The unprecedented scale of the opposition, however, failed to pressure the government for more concessions. What followed was months of protests that would often develop into chaotic and violent confrontations with the police. Yet, despite radicalization and protesters' use of violence, movement participants managed to maintain solidarity under a robust collective identity, as demonstrated by their commitment to the demands and their sustained participation (Lee, 2020). Different factions remained in unity despite their ideological and tactical disagreements. A popular slogan encapsulated the strong cohesion: 'brothers climbing a mountain, each making his own effort.'

The emergence of the Anti-Extradition Law Amendment Bill Movement (thereafter Anti-ELAB Movement) presents two classic questions for social movement scholars. How was a mobilization of this scale possible? What explains the formation of the collective identity that sustained this intensive and protracted wave of protests? These puzzles were perplexing at several levels. First, the protests emerged from a long period of abeyance after the 2014 Umbrella Movement, which ushered in a widespread sense of political withdrawal and disorientation due to its failure to achieve democratic outcomes (Yuen, 2018). Annual protest events since then suffered from dismal turnouts, making way for the government to make multiple authoritarian advances. Second, the extradition bill amendment did not attract much attention when it was first tabled in February. Even though it gradually managed to gain traction, the scale of resistance in March and April was still relatively small. In the 28 April protest, only 130,000 showed up on the streets, which was a low turnout compared with the city's average mass protest. However, the 9 June protest recorded a nearly 10 -fold increase in terms of participation. Third, the movement managed to sustain for more than half a year, making it the longest in the city's history. It featured a diverse set of protest repertoire and was joined by as much as $42 \%$ of the 7-million population. ${ }^{1}$ As such, the Anti-ELAB Movement presents an important case study for social movement research, particularly for understanding how collective identities are constructed.

Although an array of historical, institutional, and cultural factors has played a role in shaping the strong mobilization power of pro-democracy activism, this paper spotlights the role of the online petition campaign in contributing to the early mass participation in the Anti-ELAB Movement. By analyzing the petition statements and interviewing petition authors, we argue that such petitions were crucial in creating myriad intermediate group identities based on pre-existing social groups, such as alumni, professions, hobbies, religious, and community groups, which induced commitment and built solidarity among people with diverse backgrounds and interests. The online mobilization of various social groups not only made the scale of resistance visible before the protests erupted, but also provided customized diagnostic and motivational frames for a diverse range of social groups to collectively perceive the threat and see the obligation to act urgently. This helps to explain why a strong collective identity could emerge shortly to precipitate the subsequent mass mobilization.

This paper makes two contributions to the study of social movements. First, our findings depart from the existing literature which mainly focuses on the role of movement groups in building a collective identity for protest mobilization. By studying a movement where traditional organizations played a peripheral role, we show how citizen-initiated online petitions resulted in the horizontal mobilization of intermediate group identities, which, in turn, linked individuals to the emerging collective and formed the basis of solidarity. In other words, collective identity can be constructed without the explicit involvement of formal or informal groups. Second, our findings demonstrate that pre-existing social identifications remain relevant in the process of collective identity formation, despite the fact that digital technologies have enabled the rapid mobilization of individuals. Rather than becoming obsolete in the digital era, social identifications provide variegated lenses through which threat can be perceived and transformed into an action-oriented collective identity that facilitates mobilization.

\footnotetext{
${ }^{1}$ The opinion poll commissioned through the Chinese University of Hong Kong's Centre for Communication and Public Opinion Survey, $N=1,574$, response rate $=29 \%$, May 2020 .
} 


\section{Collective identity in social movements}

Collective identity has been a widely used concept in social movement studies, allowing scholars to better understand why collective actions emerge and how they develop. The notion emerged as a response to the gaps left by the once dominant resource mobilization and political process models, which focus on the structural factors and shifts that give collective actors the capacities and opportunities to mobilize. By asking why collective actors become a 'collective' in the first place, collective identity scholars emphasize the need to take meanings, emotions, and other cultural factors into account when analyzing social movements. The concept has provided new perspectives on why social movements emerge, why people participate in them, why they make or do not make certain tactical choices, and what kind of outcomes social movements bring (Polletta and Jasper, 2001).

Despite its widespread usage, collective identity is also an intensely contested concept. Classically, Alberto Melucci (1989: 793) defines collective identity as 'an interactive, shared definition of the field of opportunities and constraints offered to collective action produced by several individuals that must be conceived as a process because it is constructed and negotiated by repeated activation of the relationships that link individuals to groups'. In Melucci's formulation, collective identity is not a 'thing,' but a dynamic process based on the cognitive definitions of means, goals, and field, the networking of relationships and emotional recognition between individuals (Melucci, 1996: 71). Although this definition has been widely adopted, other scholars consider collective identity as a product more than as a process. Snow defines it as 'a shared and interactive sense of "we-ness" and "collective agency" (2001). Although Snow recognizes that collective identity may be 'subject to modification and even transformation,' the set of properties that make up the initial collective identity is more or less fixed. For Snow, conceptualizing collective identity as a product better reflects its functionality in generating the impetus for people to partake in collective actions while giving them a sense of orientation.

Although these two definitions are often conflated in use, the distinction remains conceptually important. Flesher Fominaya (2010: 397) points out that the 'product' definition is fundamentally different from the 'process' definition: while the former refers more to a perception of shared attributes, goals, and interests (something that can be felt by movement insiders and outsiders), the latter is an intra-movement phenomenon [...] more concerned with shared meanings, experiences and reciprocal emotional ties as experienced by movement actors themselves through their interaction with each other' . As she puts it, 'they refer to two different things, not to two elements of the same thing.' For our research, to understand how protest mobilization is initiated, we follow Snow (2001) to consider collective identity as a product that generates a sense of agency and provides a powerful impetus to collective action, rather than as a constantly evolving process.

How does collective identity come into existence? Scholars have characterized this process as identity work,' which involves 'the generation, invocation, and maintenance of symbolic resources used to bound and distinguish the collectivity both internally and externally by accenting commonalities and differences' (Snow, 2001). Charles Tilly identifies 'boundary activation' as a core mechanism in the process (Tilly, 2004: 226), which distinguishes insiders from outsiders or protagonists from antagonists. In the context of social movements, this process also involves the mechanism of identity correspondence' (Snow and McAdam, 2000), referred to as the alignment or linkage of personal and collective identities. Alignment is crucial because people typically have multiple personal identities that vary in salience. Personal identities are 'attributes and meanings attributed to oneself by the actor.' They are 'self-designations and self-attributions regarded as personally distinctive,' which, in turn, entails different responsibilities and imperatives for individuals (Snow, 2001). To enable myriad individuals to be mobilized as a collective actor, shared cognitions and feelings indicative of a collective identity must center-stage at the individual level.

This process of alignment is not frictionless and costless. Scholars often see this process as work that 'normally fall to organizations' (Tarrow, 2011: 152). Gamson (1996: 235) states that 'collective identities, although they are not organizational inventions, are continually filtered and reproduced through organizational bodies. [...] [I]dentity boundaries are shaped by and shift through 
organizational activity, which itself responds to features of the institutional environment.' Saunders (2008) similarly posits that collective identity is best applied to the movement organization (or group) level, rather than the movement level. Other scholars argue that informal organizations can also generate collective identities, emphasizing the role of relational ties and networks: common positions in social networks, such as communities and informal groups, are crucial to identity formation when they are activated (Gould, 1995, 1998; Mische, 1996; Pfaff, 1996).

What happens when organizations, either formal or informal, are absent or do not feature prominently before the occurrence of social movements? This happens to leaderless or networked movements in which there are no longer any centralized movement organizations, and in which social networking tools have become the 'organizational substitutes' (Buechler, 2011: 221). Indeed, the rising prominence of digital technologies in contemporary movements has enabled the 'personalization of politics,' allowing individuals to adjoin with one another through the sharing of individually expressive 'personal action frames' (e.g., We are the $99 \%$ or Black Lives Matters) instead of collective action frames (Bennett, 2012). The result is what Bennett and Segerberg (2013) call 'crowd-enabled connective actions,' where digital technologies serve as organizational hubs to 'allocate resources, respond to external events and display transitional changes over time' in the absence of organizations (2013: 13). Although this observation has initially prompted scholars to challenge the relevance of collective identities (Juris, 2012; Bennett and Segerberg, 2013), recent scholarship insists that collective identities remain central to digitally networked movements (see Gerbaudo and Treré, 2015). Scholars have argued that social networking tools also produce collective symbols and frames for participants by means of hashtags, memes, protest avatars, stories, photography, likes, and comments, depending on their technological affordances (Monterde et al., 2015; Khazraee and Novak, 2018; Pond and Lewis, 2019). Milan (2015), for instance, conceptualizes this mode of protest as 'cloud protesting,' in which private individual experiences and narratives are given voice and visibility through the act of sharing, a process which not only pools them together, but also gives them meaning within a broader context.

\section{Social identities as intermediate group identities}

Although we agree that collective identity remains pertinent in digitally networked movements, these studies have seemingly conflated the notion of personal and collective identity when they see the sharing of the personal as the source of the collective identity. Research has yet to interrogate how the mechanism 'identity correspondence' plays out when social networking tools become the main driver of mobilization. For instance, the frame 'We are the 99\%' that was widely adopted in the global Occupy movement is seen as a personal action frame that allows people to bring in their personal grievances and identities when joining the collective. However, it is not clear why individuals feel that they are part of the $99 \%$, or how they become identified with it. What, then, underpins the cohesion between individuals and the collective? How do personal and collective identities align with each other?

This paper seeks to articulate an alternative mechanism through which pre-existing social characteristics facilitate the collective identity formation process. Although the advent of social media technologies has eliminated many boundaries for collective identity to emerge among strangers, social identities may serve as a crucial medium through which individuals come together as a collective. Social identities are identities attributed or imputed to others in an attempt to situate them in social space...grounded typically in established social roles [...] or in broader and more inclusive social categories' (Snow and Corrigall-Brown, 2015: 174). They are sometimes referred to as 'role identities' (Stryker, 1980) or 'categorical identities' (Calhoun, 1997). Social identity theorists conceptualize them as 'part of an individual's self-concept which derives from knowledge of membership in a social group (or groups) together with the value or emotional significance attached to that membership' (Tajfel, 1978: 63). They are 'cognitive tools that segment, classify and order the social environment,' which provide 'a system of orientation for self-reference' and thus 'create and define an individual's place in society' (Tajfel and Turner, 1986: 283). 
In contrast to collective identity, which operates at the group level, social identity is the characteristic of an individual (Klandermans, 2014: 3). A person's social identity can involve more than one group because individuals often have multiple social roles: one can be a doctor, a parent, a Christian, an alumnus, and a resident of a particular community at the same time. Identification with these social groups requires the process of 'depersonalization' (Turner et al., 1987: 50), which transforms individuals into group members through the recognition of the symbols, values, and fate shared by the group members (Brewer and Silver, 2000; Klandermans, 2014). This, in turn, makes people more prepared to act as a member of those groups (Turner, 1999). By invoking such commitment, social identities can serve as powerful ingredients for the swift construction of a movement collective identity within a network of strangers.

In short, who people are before they become protesters matters significantly. More importantly, these social identities remain important building blocks of protest movements even though digital technologies have rendered them less important by spotlighting the personal. By providing 'the frame within which [people] can determine where they stand on questions of what is good, or worthwhile, or admirable, or of value' (Taylor, 1989: 27), social identities allow people to see the urgency and obligation to act collectively. Specifically, in the case of the Anti-ELAB Movement, we argue that, by providing customized discursive frames, online petitions mobilized myriad social identities through which common grounds could be established with a movement collective identity against the extradition bill. In this sense, they serve as the intermediaries between the personal and the collective.

Analytically, we illustrate our argument by examining the framing process. Frames are 'schemata of interpretation' that enable individuals 'to locate, perceive, identify, and label' (Goffman, 1974: 21), and to simplify and make sense of events and occurrences around them. In social movements, frames are important meaning-making devices to 'mobilize potential adherents and constituents, to garner bystander support, and to demobilize antagonists' (Snow and Benford, 1988: 198). Two types of frames stood out in the online petition campaign. One is diagnostic frames, which highlighted the threats posed by the impending extradition bill to the sectoral interests and core values of respective social groups when the impact of the bill remained distant and obscure to most people. Another is motivational frames, which harnessed the symbols and language unique to respective social groups in order to mobilize them to take part in street demonstrations. These two types of frames, we argue, served as conduits for multiple social identities among a diverse group of strangers to converge into a robust movement collective identity.

\section{Data and methods}

Data for this paper were obtained from multiple sources: online petition statements, protest onsite surveys, and semi-structured interviews with petition authors. First, we scraped 478 anti-extradition online petitions published before 9 June 2019, using Python. We then categorized these petitions into seven groups, according to the nature of the initiating body: secondary and primary schools, tertiary institutions, professionals, hobby and rights groups, religious organizations, residential communities, and overseas Hongkongers. After removing the names of the signatories, we performed a qualitative content analysis on the Chinese version of the main statements. Our method is to read through all the petitions, search for patterns in different petition categories, and then highlight the representative sections for further analysis. Table 1 provides a summary descriptive statistics of the petitions in each petition category.

Second, to assess the impact of these petitions, we draw upon the results from onsite surveys that the first author conducted during the Anti-ELAB Movement. A total of 27 onsite surveys were conducted and 16,383 responses were collected. For this paper, however, only five surveys fielded in the early stages of the protests (between 12 June and 14 July) are utilized $(n=2,844)$. These surveys included questions regarding when protesters decided to join the protests and whether they signed the online petitions. The data allow us to understand whether the online petitions had impact on protest mobilization. Finally, we conducted four semi-structured interviews with activists who initiated 
Table 1. Characteristics of different petition categories

\begin{tabular}{|c|c|c|c|c|c|c|c|}
\hline & $\begin{array}{l}\text { Secondary and } \\
\text { primary schools }\end{array}$ & Tertiary institutions & Professionals & $\begin{array}{l}\text { Hobby and rights } \\
\text { groups }\end{array}$ & $\begin{array}{c}\text { Religious } \\
\text { organizations }\end{array}$ & $\begin{array}{l}\text { Residential } \\
\text { communities }\end{array}$ & Overseas Hongkongers \\
\hline $\begin{array}{l}\text { Number of } \\
\text { petitions }\end{array}$ & 345 & 43 & 24 & 14 & 23 & 16 & 13 \\
\hline \multicolumn{8}{|l|}{$\begin{array}{l}\text { Examples of } \\
\text { the }\end{array}$} \\
\hline $\begin{array}{l}\text { initiating } \\
\text { bodies }\end{array}$ & $\begin{array}{l}\text { - Diocesan Boys' } \\
\text { School } \\
\text { - Queen Elizabeth } \\
\text { School } \\
\text { - Tsung Tsin } \\
\text { College } \\
\text { - Methodist } \\
\text { College } \\
\text { - Tsuen Wan } \\
\text { Government } \\
\text { Secondary } \\
\text { School } \\
\text { - St. Mark's School }\end{array}$ & $\begin{array}{l}\text { - Eight } \\
\text { publicly-funded } \\
\text { universities } \\
\text { - The Hong Kong } \\
\text { Academy for } \\
\text { Performing Arts } \\
\text { - The Open University } \\
\text { of Hong Kong } \\
\text { - Hong Kong Design } \\
\text { Institute }\end{array}$ & $\begin{array}{l}\text { - Insurance } \\
\text { - Journalism } \\
\text { - Information } \\
\text { technology } \\
\text { - Advertising } \\
\text { - Architecture } \\
\text { - Social welfare } \\
\text { - Nursing } \\
\text { - Doctors } \\
\text { - Catering } \\
\text { - Legal service }\end{array}$ & $\begin{array}{l}\text { - Anime, Comic } \\
\text { and Games } \\
\text { - Horseracing } \\
\text { - Sports lovers } \\
\text { - LGBTI } \\
\text { - Environment } \\
\text { - Women } \\
\text { - New } \\
\text { immigrants } \\
\text { - Disabled }\end{array}$ & $\begin{array}{l}\text { - Baptist Church } \\
\text { - Assemblies of } \\
\text { God } \\
\text { - Chinese } \\
\text { Rhenish } \\
\text { Church } \\
\text { - Pentecostal } \\
\text { Holiness } \\
\text { Church } \\
\text { - Ling Liang } \\
\text { Church }\end{array}$ & $\begin{array}{l}\text { - Mei Foo } \\
\text { - Cheung } \\
\text { Chau } \\
\text { - Kwun Tong } \\
\text { - Sai Wan } \\
\text { - Shatin } \\
\text { - Eastern } \\
\text { - Tai Po } \\
\text { - Discovery } \\
\text { Bay } \\
\text { - Sai Kung }\end{array}$ & $\begin{array}{l}\text { Hong Kongers in } \\
\text { Australia, Japan, } \\
\text { USA, UK, Europe, } \\
\text { and Taiwan }\end{array}$ \\
\hline \multicolumn{8}{|c|}{ Chinese characters in a petition statement } \\
\hline $\begin{array}{l}\text { Average } \\
\text { length }\end{array}$ & 703 & 658 & 716 & 763 & 707 & 627 & 798 \\
\hline $\min$ & 29 & 142 & 183 & 57 & 292 & 351 & 261 \\
\hline $\max$ & 1,807 & 1,642 & 2,133 & 2,158 & 1,343 & 902 & 1,285 \\
\hline
\end{tabular}


the online petitions to understand their considerations when drafting the statements and the strategies they used to promote them.

\section{Hong Kong's Anti-Extradition Law Amendment Bill Movement and before}

Hong Kong has developed a vibrant culture of civic activism since the late colonial period, which began with the various socio-economic reforms in the 1970s and then shifted to demands for electoral democracy in the 1980s (Lam, 2004). After the sovereignty handover in 1997, Hong Kong experienced several waves of mass mobilization, such as the 1st July Demonstration in 2003, the heritage activism and the Anti-Express Rail Campaign between 2004 and 2010, the Anti-National Education Movement in 2012, and the Umbrella Movement in 2014. Several factors contributed to these mass mobilizations shared political memories and the pursuit of core values (Davis, 2015; Cheng and Yuen, 2019), threats posed by the semi-authoritarian government (Ho, 2019), anti-mainland sentiments (Ma, 2015), and cross-boundary integration (Yuen and Cheng, 2020). However, Hong Kong entered a period of movement abeyance after the Umbrella Movement when several pro-democracy citizens were traumatized by their failure to achieve any democratic reforms and the tension between the moderate and the radical-localists was deepening (Yuen, 2018). Although the civil society managed to preserve and develop their grassroots networks, cultural ties, and preserve civic values that paved the road for future mobilization (Cheng et al., forthcoming), social movement organizations were unable to mobilize people against controversial policies - for example, the implementation of the co-location arrangement of the Guangzhou-Shenzhen-Hong Kong Express Rail Link in 2018.

The distant root of the Anti-ELAB Movement can be traced back to February 2018, when a young woman from Hong Kong, Amber Poon, was murdered by her boyfriend Chan Tong-Kai in Taiwan. Before the police identified him as a suspect, Chan flew back to Hong Kong and admitted his crime to the local authorities. As Hong Kong does not have an extradition treaty with Taiwan, Chan could not be extradited legally. In February 2019, the Hong Kong government announced its intention to introduce a regular extradition mechanism to transfer fugitives to Taiwan. However, the proposed amendment would also allow Hong Kong to surrender fugitives to Macau and Mainland China, with which it does not have extradition agreements. Officials insisted that the measure was to 'plug the legal loopholes' and prevent Hong Kong from becoming a haven for criminals.

The proposal gradually sparked fears among the public. Citizens became worried that the Chinese government could use the arrangement to extradite political opponents from the semi-autonomous territory. This could remove the legal firewall between Hong Kong and the Mainland, effectively ending 'One Country, Two Systems.' From March to May, pro-democracy groups began to mobilize a series of protests. However, the turnout of these early protests remained low. Although the 28 April protest organized by the Civil Human Rights Front claimed an attendance of 130,000 people, the scale of mobilization could hardly compare with several previous protests in Hong Kong - an example of which was the 2003 1st July Demonstration when 500,000 people rallied. Interest among young people was particularly weak, as many were still traumatized by the failure of the 2014 Umbrella Movement to achieve its pro-democracy goals (Yuen, 2018).

Opposition against the bill gained momentum in May, as pro-democracy lawmakers escalated their opposition by filibustering the bill in Legislative Council. This prompted the government to fast-track the amendment, which was met by stronger opposition from lawmakers. It was only until then, around late May, that a sizeable opposition began to form on the Internet, galvanized through a series of online petitions. The first petition was initiated by the teachers and alumni of St. Stephen's College, the alma mater of the murder victim, on 27 May. The initiators urged the government not to take the advantage of Poon's murder to amend the extradition law. ${ }^{2}$ Several other secondary schools followed suit - the most remarkable of which were the alma maters of the key officials, such as

\footnotetext{
${ }^{2 ‘}$ Petition statement by alumni, students and teachers of St. Stephen's College.' Retrieved 16 July 2020 (https://bit.ly/ 2CmOfRx).
} 
St. Francis' Canossian College, where the Chief Executive Carrie Lam studied. The tide rippled from education institutions to different professional sectors, religious groups, hobby groups, and residential communities. In a few days, several hundreds of petitions were circulated on the Internet, and people shared them through different social media platforms. At least 270,000 people signed these petitions by 8 June, a day before the first protest. ${ }^{3}$

Despite having similar format and demands, the petitions had high degrees of originality in terms of their content, tone, and choice of words. All of the petitions started with a political statement drafted by the initiators to cater to their intended audience. One interviewee, who initiated a statement for her school, recalled that she 'drafted it quickly during a boat ride... using her experience as a policy researcher.' But, she insisted that she did not copy from other statements because she wanted it to be original to 'reflect the character of [her] school." Another petition author said that she and her co-initiators decided to use a more professional and objective tone to appeal to other graduates, who are mostly middle-class professionals. ${ }^{5}$ They also sought to strategically highlight one particular dimension of the bill - the potential confiscation of private property - in order to solicit graduates' support. Other types of petitions also had their unique features. The information technology workers' petition, for instance, began the statement with quasi computer programing language: if (law.pass) die (). Meanwhile, the petition for homemakers was written entirely in colloquial Cantonese - rather than formal Chinese - and it used simple, layman language to put the bill in perspective.

Besides introducing the background of the extradition and detailing the rationale for opposing it, several of these petitions also included a call for action to inform signatories about the 9 June protest. Out of the 478 petitions collected by the authors, we found that 295 , or $62 \%$, contained information about the scheduled protest, including date and venue. As these petitions went viral online, there was a strong expectation that the protest on 9 June would have a large turnout. On that day, protesters took to the street on a scale unseen after 1989 when Hong Kong citizens rallied to support pro-democracy protesters in Beijing. Organizers announced that 1 million people had participated in the protest. The figure was surpassed only a week later when an estimated 2 million protested again. In the following months, protests continued to grow and became increasingly violent as the police switched to more repressive tactics, which prompted new demands for political and police reforms.

These online petitions played an important role in galvanizing the opposition to the extradition bill into this months-long, territory-wide movement. Although there were also other factors at work that led to the million-strong rallies, including the filibuster drama in the legislature and the intensive media coverage on the extradition bill, the petitions contributed significantly by visualizing the scale of opposition and activating different civil society networks. The critical role of the petitions was supported by data from the protest onsite surveys. In the four rounds of survey conducted between 16 June and 14 July, more than $80 \%$ of respondents, on average, signed the petitions - except for the 16 June protest which was disproportionately bigger in size (see Fig. 1). In all five rounds of the survey, we found that consistently more than $40 \%$ of the respondents decided to join the protests during the petition campaign in late May, compared with other critical entry points to the movement (see Fig. 2). Our participation observation on the 9 June protest lends further support: among the 182 participating groups, 30 were secondary schools that had initiated petitions - most of which carried flags printed with their school's name. Interviews with petition authors from two of these schools suggested that they coordinated with one another before the protest through a private Facebook group to order the flags in bulk. ${ }^{6}$ It is important to note that given the lack of the counterfactual we do not know the exact contribution of the petitions to the protest turnout. However, as far as the data suggest, there is strong evidence pointing to the pivotal role of the petitions.

\footnotetext{
${ }^{3}$ HKCNEWS. 2019. 'A Collection of Anti-extradition Bill Petitions.' Retrieved 16 July 2020 (https://www.hkcnews.com/ FOO-petitions/\#/). The actual figure should be more than its collection.

${ }^{4}$ Anonymous petition initiator. (29 May 2020). Personal interview.

${ }^{5}$ Anonymous petition initiator. (5 June 2020). Personal interview.

${ }^{6}$ Two anonymous petition initiators. (7 June 2020). Personal interview.
} 
Question: Did you sign an online petition?

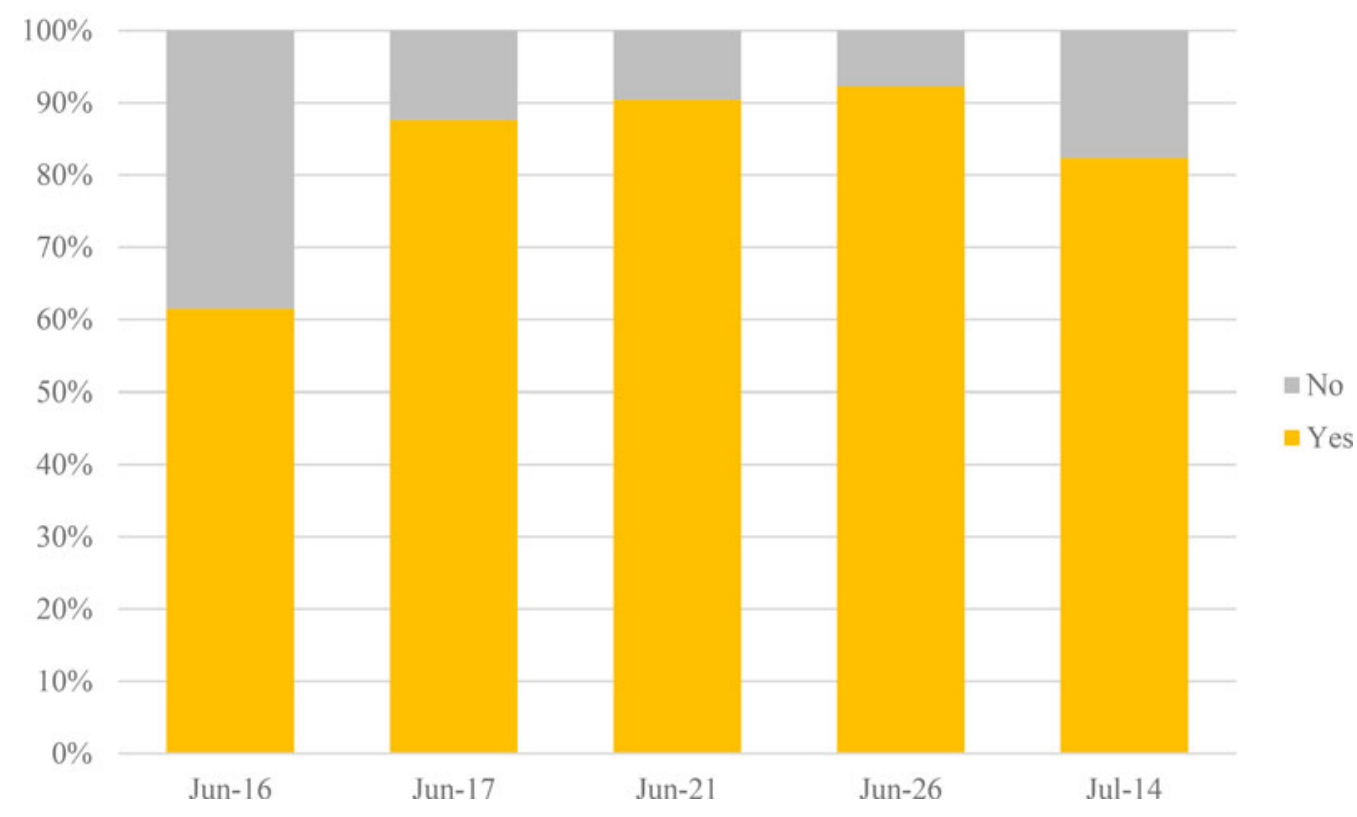

Figure 1. Petition signing among protesters.

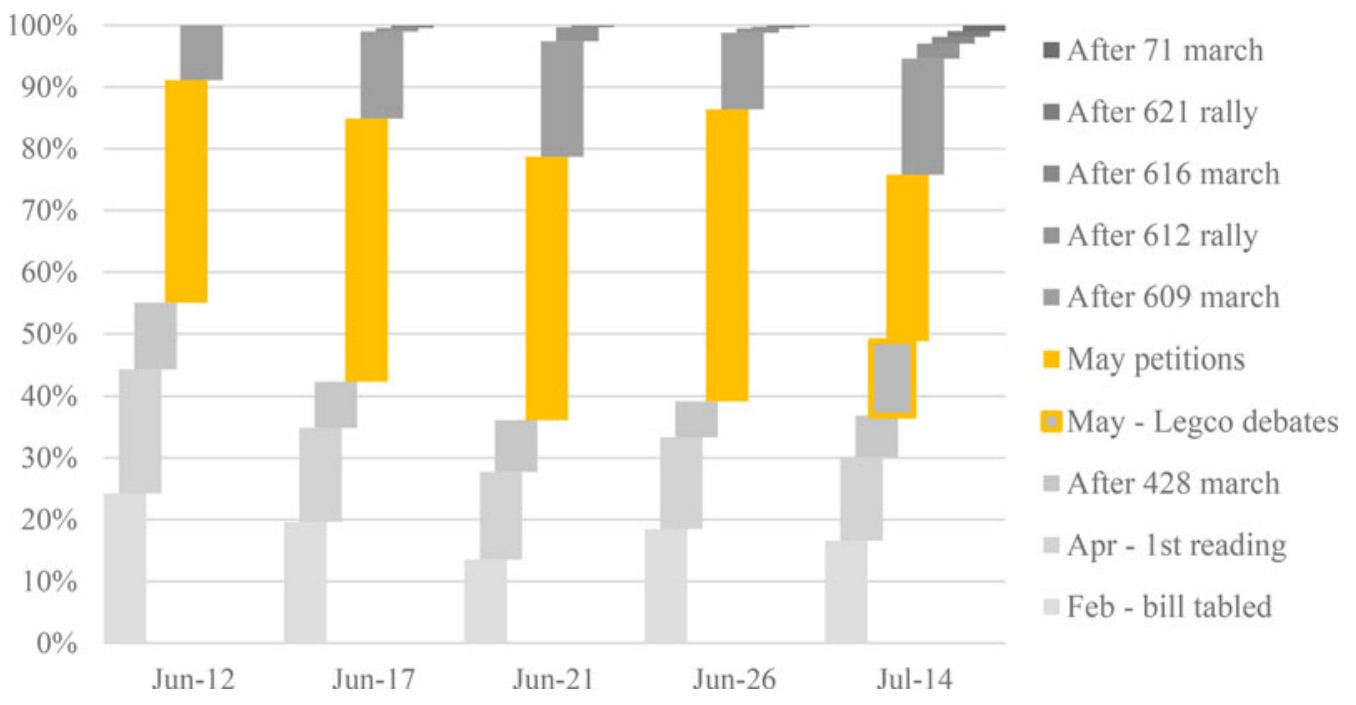

Figure 2. Time period at which protesters decided to join the movement.

\section{Framing solidarity}

How did the online petitions move dissent from digital to offline space? In this section, we argue that it was the social identities mobilized through the petitions that served as an important mediator between words and actions. Earlier on, following insights from social identity theories, we posit that group identification is a process of transforming individuals into group members through the recognition of the symbols, values, and fate shared by them. To understand how this process leads to the formation 
of a protest-inducing collective identity, we focus on the role of framing in the petitions. In our analysis, we examine two types of frames - diagnostic and motivational frames - that were particularly salient across the petitions. For diagnostic frames, we focus on the framing of threat posed by the extradition bill to various social groups. Threats, along with political opportunities, shape decisions of collective mobilization (Snow et al., 1998; Almeida, 2019). However, threats are not always visible and palpable. They have to be put into perspectives and perceived by the social actors (McAdam and Tarrow, 2019). This process of threat framing is often mediated by the social structures in which individuals are embedded, such as family, friendship, local relation, and national authority, which provide access to information critical for mobilization decisions (Shesterinina, 2016). Following this perspective, we propose that group identities can provide variegated lenses for different social groups to make sense of collective threats, leading them to participate in protests. For motivational frames, we focus on the identity component which entails the process of defining a 'we,' the movement protagonist (Gamson, 1992). This directs us to examine the symbols and values invoked by different social groups to create a feeling of shared fate and a sense of urgency and duty to act, including collective memories, mottos, principles, vocabularies, and languages.

By highlighting the threats and emphasizing the obligation to act, the petitions thus served to strengthen people's identification with their social groups in heterogeneous ways. They created multiple action-oriented social identities which were then transformed into the collective identity that undergirded the movement claims. The nascent collective identity was not simply the amalgamation of the intermediate group identities. It was instead their common denominators where these group identities overlapped with one another - their shared opposition against the extradition bill, their disdain toward police actions, and their aspiration for a democratic Hong Kong. Without the use of these intermediate group identities to perceive threats from their own perspectives, it would have been more difficult for strangers to transform into a movement collective, especially when a centralized leadership was lacking. The latter issue is particularly relevant to the context of Hong Kong, where social movement organizations often played a peripheral role in popular protests. Lee and Chan (2018) argue that protests in the city are characterized by a culture of citizen self-mobilization. In their earlier study on the 1 July 2003 rally (Lee and Chan, 2011), they show that only 6.4\% of the protesters were active members of any social or political groups. Protesters also did not see the calls to action by political figures and social movement organizations as important to their decision to participate. This culture of organizational detachment provides important background for understanding why intermediate group identities could be an enabling factor of citizen self-mobilization.

\section{Diagnostic frames: personal security, economic interests, and core values}

Diagnostic framing concerns the identification of social problems and attribution of blame to the relevant parties, thus providing would-be participants with the cognitive rationales to engage in collective actions (Snow and Benford, 1988). This was a core task of the online petitions because, at first, the public was lukewarm to the extradition bill. Indeed, before May, the legal implications of the amendment remained distant to the majority of citizens. Besides, the government had framed the amendment as a righteous move to do justice to the murder victim. Implications only became clearer as the motion debate unfolded in the city's legislature and attracted media attention. However, it was the online petitions emerging in late May that put these implications into perspective. By diagnosing the bill amendment from the lens of different social groups, these online petitions were able to highlight various types of threats that give people the cognitive basis to act.

The most common diagnostic frame is the threat of the bill to civil liberty and personal security. One notable characteristic is that several of the petitions would simply frame the extradition bill as the 'send-to-China law' (sungjung tiulai), implying that Hong Kong citizens could be sent to China by brute force. In Cantonese or Mandarin, the phrase 'send-to-China' is also a homophonic variant of 'attend upon a dying parent' (sungjung), which adds further metaphoric meaning. This frame was particularly salient among petitions initiated by professional groups whose members need to travel 
frequently to Mainland China. For example, the petition initiated by the education sector, drafted by four teacher alliances, states that:

'[E]xchanges between teachers of universities, secondary schools, primary schools and kindergartens, and their Mainland counterparts are common; teachers taking students on Mainland study tours are also increasing. Hong Kong people generally lack confidence in the Mainland's law enforcement system. In the past, there were instances in which Hong Kong citizens were kidnapped back to the Mainland, but they remained secretive and illegal. If the law passes, the risk of people being extradited will increase tremendously."

Other professional sectors, such as insurance, architecture, surveying, and journalism, whose work requires frequent travel to the Mainland, expressed similar concerns in their petitions. They commonly highlighted the need to engage in cross-border activities, the potential legal risk as well as the differences in legal standards between Hong Kong and Mainland China. For example, the journalists' petition featured the story of Hong Kong publisher Yiu Man-tin, who published books about the Chinese political leadership and was sentenced to 10 years' imprisonment for smuggling charges in $2014 .^{8}$ Petitions initiated by hobby or rights groups, such as animation fans, LGBT people, and animal rights activists, were no exception in utilizing this 'send-to-China' frame. The petition initiated by animation fans, for instance, referred to the case of a Chinese Boys' Love novelist Tianyi and her collaborators, who were imprisoned for a maximum of 10 years for publishing erotic and homosexual content, as an alarm for novelists and readers in Hong Kong.'

Another type of diagnostic frames was that sought to highlight the impact of the extradition bill on Hong Kong's economic interests, which was particularly salient among the professional sectors. For instance, the accountants' petition mentioned the risks that accountants might face under the new law due to their intricate working relationships with Chinese companies. It also highlighted the potential economic repercussions: '[The bill] would expose the practitioners to legal risks, which will tarnish Hong Kong's image as an international financial center and will bring about economic losses. ${ }^{10}$ This was also the case for the arts and cultural professionals, who wrote in their petitions that the law would obstruct foreign artists from coming to Hong Kong, thus hurting the city's image as an international cultural hub. ${ }^{11}$ Interestingly, the perception of economic devastation was not limited to the professionals. Even blue-collar workers saw the extradition bill as a grave threat to their livelihood. For instance, the petition started by catering workers stated that:

'From an economic perspective, if the bill is passed, there will be a new wave of mass emigration and divestment. The catering industry will certainly be affected, and the grassroots workers will of course suffer first. ${ }^{12}$

Highlighting the economic impact was crucial to the process of threat framing. Although prodemocracy activists had described the extradition bill as a fatal blow to the city's autonomy and status as an international financial center, the petitions served to emphasize the tangible consequences of the bill for people in different social sectors. In other words, they put things in perspective and link the individuals to group interests in the spirit of 'depersonalizing' members of the groups.

\footnotetext{
${ }^{7}$ 'Statement of the Education Sector: Demanding Government Withdrawal of the Fugitive Offenders Ordinance Amendment bill.' Retrieved 16 July 2020 (https://bit.ly/2CaioUc).

${ }^{8}$ Hong Kong Journalist Association. 2019. 'Joint Statement: Media Organizations Oppose Fugitives Transfer Bill.' Retrieved 16 July 2020 (https://www.hkja.org.hk/en/statements/joint-statement-media-organisations-oppose-fugitives-transfer-bill/).

9'Petition statement by Anime-Comic-Doujin Industry Social Concern Group Hong Kong.' Retrieved 16 July 2020 (https:// bit.ly/3fCp0c5).

${ }^{10}$ Petition Statement by Accountant and Accountancy Practitioner.' Retrieved 16 July 2020 (https://bit.ly/3h5lE1M).

${ }^{11}$ 'Petition Statement by the Practitioners in the Fields of Sports, Performing Arts, Culture and Publication.' Retrieved 16 July 2020 (https://bit.ly/2B4IsiK).

${ }^{12 ‘}$ Petition Statement by Practitioner of Catering Industry.' Retrieved 16 July 2020 (https://bit.ly/3hIWA1S).
} 
In contrast, for non-professional bodies such as secondary schools, universities, and religious organizations, the diagnostic framing strategy focused on the threat of the bill toward rights and moral values. This was likely because these sectors do not have as many linkages as the professional sectors with Mainland China, and hence their petitions did not talk about economic consequences as much. Among the petitions drafted respectively by different Christian organizations, a common theme was how the extradition bill posed a threat to Christian values. For instance, the petition from the Christian and Missionary Alliance wrote that 'since the Creation mankind has been endowed with sacred dignity and freedom, including rights expressed in the Universal Declaration of Human Rights adopted by the United Nations; and we are only the housekeeper of the earthly world. ${ }^{, 3}$ The Hong Kong Tsz Kwong Bethel Church similarly stated in its petition:

'As Christians, we believe that God gives every government the duty to uphold peace, fairness and freedom, such that the Church can obey God, serve Jesus Christ and preach the gospel without hindrance...but given that the extradition law could be applied retrospectively, Hong Kong church may infringe Mainland religious law without knowing it. Religious freedom will be threatened.' ${ }^{14}$

Secondary schools' petitions, meanwhile, tended to focus on the erosion of moral values under the extradition bill. Their statements often referred to moral doctrines that schools typically impart on students, such as truth, justice, and conscience. For instance, the petition started by students and alumni of Heep Woh College stated that:

'At the hall on the first floor of our school hangs our school motto: 'When you know the truth, the truth will set you free.' Every year, when new students arrive, our principal always explains the meaning of these words and reminds us to remember them by heart. Hong Kong is now turning authoritarian, and truth has been distorted and evaded. At this very moment, we especially need to defend truth and voice out for universal values such as human rights and freedom. ${ }^{\text {,5 }}$

The petition of Kei Yuen College, similarly, emphasized how the bill contradicted the school's mission. Citing its four-point mission statement, ${ }^{16}$ the petition asked rhetorically:

'Can students be happy under this absurd education system? Can teachers provide quality education under this restrictive environment? Can students develop their potential? If our next generation loses their freedom, can their lives still be fulfilling? ${ }^{17}$

Examples like these were prevalent among secondary school petitions. By underscoring the harmful impact of the extradition bill on the fundamental tenets promoted by schools and religious institutions, these petitions framed the movement as a black-and-white struggle, attempting to strengthen the cognitive imperative to oppose the bill as a group.

\section{Motivational framing: creating the moral imperative to act}

Although diagnostic framing defines problems and attributes blame, motivational framing offers the 'call to arms' for would-be participants to join collective action (Snow and Benford, 1988). This often

\footnotetext{
${ }^{13}$ 'Statement by People from Christian and Missionary Alliance.' Retrieved 16 July 2020 (http://bit.ly/2wcVLHX).

${ }^{14 ‘}$ 'Statement by People from Tsz Kwong Bethel Church.' Retrieved 16 July 2020 (http://bit.ly/2JIaAef).

${ }^{15}$ 'Petition Statement by Alumni, Teachers and Students of CCC Heep Woh College.' Retrieved 16 July 2020 (https://bit.ly/ 2UXHH1I ).

${ }^{16}$ CCC Kei Yuen College. 'School Information.' Retrieved 16 July 2020 (http://ccckyc.edu.hk/ccckyc/school-information/).

${ }^{17}$ 'Petition Statement by Alumni, Teachers and Students of CCC Kei Yuen College.' Retrieved 16 July 2020 (https://bit.ly/ 3dcQ4Nn).
} 
involves making appeals that resonate within the emotional state and the cultural milieu of the targeted populations (Almeida, 2019). Motivational framing was also a crucial task for the petitions because their objective was not only to inform different social sectors about the bill, but also to mobilize them to join the 9 June protest. Thus, apart from including the protest call, the petitions often appealed to symbols and collective memories to evoke a sense of belonging to the respective groups and thus create a moral imperative to act. This was particularly the case for the petitions of secondary schools, which are a common experience for every citizen. For instance, the petition of St. Catharine's School for Girls wrote:

'We are in the midst of a raging storm. In the face of social injustice, we should scrupulously follow the motto of our alma mater: Brave, Gentle, Sincere. When it comes to being Good, we defer to no one and will actively voice out. ${ }^{18}$

The petition of Wah Yan College Kowloon similarly stated:

'Our alumnus, Secretary for Security, John Lee ignored public opinion and pushed forward the extradition law amendment bill. As alumni, students and teachers, we deeply regret his actions. Seeing Hong Kong's liberty and rule of law under attack and its international status at risk, we must uphold the spirit of the Society of Jesus, 'Men for Others' and we shall not turn a blind eye to the issue... We will insist to follow our school motto: by this sign, we shall conquer. ${ }^{, 19}$

By invoking the school motto and the moral principle of the school's Catholic sponsoring body, the statement portrayed opposition to the extradition bill as a duty of the Wah Yan community. It also depicted John Lee, a key official responsible for introducing the bill, as a symbolic figure who had breached the school's founding principles, while praising two other alumni, Martin Lee and James To, both pro-democracy politicians, for their effort in opposing the bill. This name-and-shame strategy, which aimed to create a symbolic opposite of the moral imperative, was also found in several school petitions. The joint petition of two schools, St. Francis Xavier's College and St. Francis Xavier's School, stated:

'Xaverians cherish freedom, human rights, critical thinking and fraternity. The true spirit of fraternity is not about 'social harmony' on the surface; it means making decisions that can bring stability and justice to our society and the next generation. Some of our alumni have become key government officials. They should insist on what they have learnt in the alma mater and be the Xaverians that show commitment to our society. ${ }^{20}$

The petition indirectly pointed to two graduates, both high-ranking government officials, for contravening the spirit of Xaverians. It is also important to note that this petition, unlike several others, was a joint statement by two 'brother schools.' Despite being located in two different districts, students from both schools decided to issue a joint statement to showcase their solidarity as Xaverians, emphasizing their sharing of the same set of values.

The petition initiated by Workers' Children Secondary School presented a unique example to demonstrate how motivation framing was employed to mobilize actions. In contrast to several other schools in Hong Kong that have religious affiliations, the school has a pro-Communist background that could be dated back to its establishment in 1946. Given its background, one would expect that there would be little dissent against the extradition bill. Nevertheless, students from the school issued a critical statement against the bill:

\footnotetext{
${ }^{18}$ 'Petition Statement by Alumni of St. Catharine's School for Girls.' Retrieved 16 July 2020 (https://bit.ly/32q7kNf).

${ }^{19}$ 'Petition statement by Alumni, Teachers and Students of Wah Yan College Kowloon,' collected by the authors.

${ }^{20}$ 'Petition Statement by Alumni and Students of St. Francis Xavier's College and St. Francis Xavier's School.' Retrieved 16 July 2020 (http://bit.ly/2wlalx6).
} 
'Although our alma mater has long promoted the education of 'Love the Country, Love Hong Kong,' we understand that 'Love the Country' does not mean 'Love the Party [Communist Party]' and that 'Love Hong Kong' does not imply 'Love the ruler.' Students should follow our school motto to make China and Hong Kong better places with passion, honesty, truth-seeking and innovation. Let Hong Kong people enjoy freedom and democracy as well as preserve the legal system that we are proud of, so Hong Kong can become our cozy home where we can settle down. $^{21}$

This petition is unique in the sense that it presented itself as a rational, constructive voice speaking to the authorities by invoking the patriotic, pro-Beijing identity of the school. By engaging with a discursive struggle over the meaning of patriotism, the petition skillfully framed opposition against a government-proposed law as a patriotic and non-confrontational action that would be beneficial to the country.

Apart from creating the moral imperatives through the invocation of a sense of belonging, the online petitions also sought to appeal to the cultural milieu of different social sectors by using specialized words or styles of writing. The petition written by IT workers, which began with a syntax of computer programing, is an apt example. Another pertinent example was the petition started by a group of animation, comics, and games fans, which used a dramatic and imaginative style characteristic of these genres to frame the statement:

'Year 2020, the 'send-to-China' extradition bill is implemented in Hong Kong. A 'Dark Age' has arrived. Cartoonists are arrested, and people can only watch animation under surveillance.... Will this become the future? We need to stop it together.' ${ }^{22}$

In other cases, petition authors deliberately used vernacular Cantonese to draft the statement, rather than the formal written Chinese commonly used in official statements. Besides the petition written by the homemakers, this linguistic style was also found in those initiated by the construction workers and the catering workers. For instance, when describing the potential risks of the extradition bill, the catering workers' petition used Cantonese slangs 'Lou Wat' to denote 'false accusation' and 'Chai Sang Jyu Yuk' (literally means raw pork) to stand for 'planting of evidence.' This may well be intended for the layman and less educated to understand the implications of the bill in their own terms instead of through the jargons used by elites. It may also be a discursive strategy to resonate with the concerns of ordinary citizens and define their social group identities.

So far, the petitions have been largely analyzed from a top-down perspective in that it was the authors who decided what to include in the statements and what writing style should be adopted. However, although authors could indeed dictate the content, style, and tone of the statements, it is important not to neglect the bottom-up, participatory elements. The homemakers' petition, for instance, allowed signatories to leave messages regarding their feelings and attitudes toward the extradition bill, which would be updated on its Google Form page. A cursory glance over these messages showed the following examples:

'Do not think that housewives don't care about worldly affairs and that you can do whatever you want. In critical moments, we will stand out to uphold justice.'

'Finally, there is a petition that fits who I am. I am already an old woman and may not have a long future, but how does the next generation continue? If this law passes, I will owe the younger generation a lot. I need to voice out when I still can and do as much as possible. ${ }^{23}$

\footnotetext{
${ }^{21 ‘}$ Petition Statement from Alumni, Students, Ex-teaching Staff and Current Teaching Staff of Workers' Children Secondary School (currently called Scientia Secondary School),' collected by the authors.

${ }^{22}$ 'Petition Statement by Anime-Comic-Game Practitioners and Fans.' Retrieved 16 July 2020 (https://bit.ly/2OwAS3N).

${ }^{23 ،}$ Petition by Hong Kong's Housewives.' Retrieved 16 July 2020 (https://bit.ly/3fFa2lN).
} 
A final point to highlight is that petitions did not only comprise a plain statement. They also include a long list of signatories which showed the endorsement they received, and which lent them credibility. This, of course, depends on how 'real' the signatures are - and this may be helped by the 'details.' Among the school and university petitions, for instance, signatories signed not only their name, but also their year of graduation, sometimes their class if they were current students. Animation, comics, and games fans indicated along with their names their specific types of interest, such as cosplay, digital games, and manga. In the petitions started by new Chinese immigrants, signatories were asked to state the year they arrived in Hong Kong. The petition for residents in Discovery Bay, a gated community, even asked signatories to indicate the block that they were living in. ${ }^{24}$ Such information served to increase the credibility of the petitions in the sense that those who signed were not just names, but individuals with real lives and identities. In effect, they contributed to a sense of 'we-ness' in the respective social groups, strengthening their propensity to take part in collective actions.

\section{Conclusion}

Collective identity is a crucial element in the formation of social movements. This paper has explained how collective identity comes into existence among people of diverse backgrounds in Hong Kong's Anti-ELAB Movement through what we call intermediate group identities. Although the advent of digital technology has made it easier for strangers to come together for a common cause, we argue that pre-existing social identities retain an important role in mediating people's decision to participate in social movements. In analyzing the online petition campaign prior to the beginning of the movement, we demonstrate how a diverse range of intermediate group identities - alumni, professions, hobbies, and community groups - served as conduits to foster solidarity within a group-level before constituting a larger collective identity that propelled the movement.

Content analysis of the petition statements showed that these intermediate social identities offered discursive resources for a diverse range of actors to find commonalities through two mechanisms: diagnostic and motivational framing. By identifying the threats posed by the bill and drawing upon symbolic resources from various identity groups respectively, these two types of movement frames created cognitive and moral imperatives to act collectively as group members. This is not to simply say that people are students, alumni, residents, professionals, churchgoers, or pet lovers before they become protesters. Rather, people became protesters because they recognized themselves as belonging to these social identity groups. Through the lens of these roles, they see the importance to act together and to act urgently.

These intermediate group identities became the base ingredients that allowed a collective identity to quickly formulate early on in the Anti-ELAB Movement despite the absence of any formal movement leadership. This nascent collective identity was no longer group-based like the group identities; it was constituted by the shared opposition against the extradition bill, disdain toward police actions, and aspiration for a democratic Hong Kong. It was also strengthened and transformed through various protest events, and in response to the increasingly repressive state actions. However, although this collective identity center-staged in the movement, group identities did not entirely disappear. Several subsequent protests were, in fact, organized by different social groups for their ingroup members. For example, there were protests organized by mothers, lawyers, accountants, teachers, social workers, Christians, or secondary school students. These protests often carried distinctive characteristics of the social groups. In the lawyers' protests, for instance, in seeking to show dissent in a professional manner, participants would dress in black suits and march silently in the business district. In the students' protests, a lot of music performances and personal sharing would be featured in the protest rundown, which was intended to appeal to the young students.

\footnotetext{
${ }^{24}$ 'Joint Statement of Discovery Bay Residents against the Extradition Law Amendment.' Retrieved 16 July 2020 (https://bit. ly/3di21RE).
} 
Although this paper offers insights into the formation of movement collective identity through its discursive mechanisms, some important puzzles remain unresolved - particularly regarding the evolution of the collective identity. This paper has only focused on the online petition campaign during the early stage of the movement, which continued into the rest of 2019 until the COVID-19 pandemic broke out in Hong Kong. The protests have also diffused into other forms of activism such as industrial unionization, political consumerism, and international lobbying. Although the initial movement collective identity can partly account for the energy and momentum of the protests, it is important to acknowledge that this same identity was constantly re-negotiated through the interactions among protesters and in response to events that unfolded throughout the movement, much in line with what the constructivist theorists have argued based on the framework of Alberto Melucci. For instance, the strong solidarity between moderate and radical protesters despite a trend toward tactical radicalization was heavily shaped by their common experiences, such as fleeing collectively from the police and facing police brutalities (Lee, 2020). Our analysis only focuses on the incipient collective identity but cannot account for its subsequent evolution.

Second, although this paper generally argues that pre-existing social identifications remain relevant in the formation of collective identity, it could not distinguish the effect of different forms of social identities on the construction process. We do not have evidence to demonstrate whether social identities, such as school, professional, or neighborhood, have stronger mobilizational effects than others. Third, given the ongoing repression of Hong Kong's pro-democracy activism, including the introduction of the National Security Law in 2020 that outlaws several forms of dissents, the conditions under which the above movement collective identity came into existence were no longer the same. Although similar online petitions had emerged to oppose the new law, they were simultaneously sabotaged by pro-government groups (e.g., by flooding the online forms with fake names) and emulated by the same groups to manufacture support. The disbandment of the Hong Kong Professional Teachers' Union, pro-democracy trade unions, and university students' unions in 2021 also showed that the government has systematically cracked down on professional and student networks, hampering their mobilization capacity online and offline. Our study also could not account for these changes. Further research should be devoted to studying how collective identity changes in conjunction with social identities, especially when the movement is forced into abeyance.

Financial support. This study was supported by the Public Policy Research Funding Scheme, HKSAR (SR2020.A3.007).

Conflict of interest. The authors declare that there is no conflict of interest.

Supplementary material. The supplementary material for this article can be found at https://dataverse.harvard.edu/dataset. xhtml?persistentId=doi:10.7910/DVN/KDRRSX.

\section{References}

Almeida P (2019) Social Movements: The Structure of Collective Mobilization. Oakland: University of California Press. Bennett WL (2012) The personalization of politics: political identity, social Media, and changing patterns of participation. The Annals of the American Academy of Political and Social Science 644, 20-39.

Bennett WL and Segerberg A (2013) The Logic of Connective Action: Digital Media and The Personalization of Contentious Politics. New York: Cambridge University Press.

Brewer MB and Silver MD (2000) Group distinctiveness, social identification, and collective mobilization. In Stryker S, Owens TJ and White RW (Eds.), Self, Identity, and Social Movements. Minneapolis: University of Minnesota Press, pp. 153-171.

Buechler SM (2011) Understanding Social Movements: Theories from the Classical Era to the Present. Boulder: Paradigm Publishers.

Calhoun C (1997) Nationalism. Buckingham: Open University Press.

Cheng E and Yuen S (2019) Memory in movement: collective identity and memory contestation in Hong Kong's Tiananmen vigils. Mobilization: An International Quarterly 24, 419-437.

Davis M (2015) Beijing's broken promises. Journal of Democracy 26, 101-110.

Flesher Fominaya C (2010) Collective identity in social movements: central concepts and debates. Sociology Compass 4, 393-404. 
Gamson WA (1992) Talking Politics. New York: Cambridge University Press.

Gamson J (1996) The organizational shaping of collective identity: the case of lesbian and Gay film festivals in New York. Sociological Forum 11, 231-261.

Gerbaudo P and Treré E (2015) In search of the 'we' of social Media activism: introduction to the special issue on social Media and protest identities. Information, Communication \& Society 18, 865-871.

Goffman E (1974) Frame Analysis: An Essay on the Organization of the Experience. New York: Harper Colophon.

Gould RV (1995) Insurgent Identities: Class, Community, and Protest in Paris from 1848 to the Commune. Chicago: The University of Chicago Press.

Gould RV (1998) Political networks and the local/national boundary in the whiskey rebellion. In Hanagan MP, Page Moch L and te Brake W (eds.), Challenging Authority: The Historical Study of Contentious Politics. Minneapolis: University of Minnesota Press, pp. 36-53.

Ho M-s (2019) Challenging Beijing's Mandate of Heaven: Taiwan's Sunflower Movement and Hong Kong's Umbrella Movement. Philadelphia: Temple University Press.

Juris JS (2012) Reflections on \#occupy everywhere: social media, public space, and emerging logics of aggregation. American Ethnologist 29, 259-279.

Khazraee E and Novak AN (2018) Digitally mediated protest: social media affordances for collective identity construction. Social Media + Society 4, 1-14. doi: 2056305118765740

Klandermans B (2014) Identity politics and politicized identities: identity processes and the dynamics of protest. Political Psychology 35, 1-22.

Lam WM (2004) Understanding the Political Culture of Hong Kong: The Paradox of Activism and Depoliticization. Armonk, New York: ME Sharpe.

Lee FLF (2020) Solidarity in the Anti-Extradition Bill Movement in Hong Kong. Critical Asian Studies 52, 18-32.

Lee FLF and Chan JM (2011) Media, Social Mobilization and Mass Protests in Post-Colonial Hong Kong. London: Routledge.

Lee FLF and Chan JM (2018) Media and Protest Logics in the Digital Era: The Umbrella Movement in Hong Kong. New York: Oxford University Press.

Ma N (2015) The rise of 'anti-China' sentiments in Hong Kong and the 2012 legislative council elections. The China Review 15, 39-66.

McAdam D and Tarrow S (2019) The political context of social movements. In Snow D, Soule SA, Kriesi H and McCammon HJ (eds), The Wiley Blackwell Companion to Social Movements. Oxford: Blackwell, pp. 17-42.

Melucci A (1989) Nomads of the Present: Social Movements and Individual Needs in Contemporary Society. London: Hutchinson Radius.

Melucci A (1996) Challenging Codes: Collective Action in the Information Age. Cambridge: Cambridge University Press.

Milan S (2015) From social movements to cloud protesting: the evolution of collective identity. Information, Communication \& Society 18, 887-900.

Mische A (1996) Projecting democracy: the formation of citizenship across youth networks in Brazil. International Review of Social History 40, 131-158.

Monterde A, Calleja-López A, Aguilera M, Barandiaran XE and Postill J (2015) Multitudinous identities: a qualitative and network analysis of the $15 \mathrm{M}$ collective identity. Information, Communication \& Society 18, 930-950.

Pfaff S (1996) Collective identity and informal groups in revolutionary mobilization: east Germany in 1989. Social Forces 75 , 91-117.

Polletta F and Jasper JM (2001) Collective identity in social movements. Annual Review of Sociology 27, 283-305.

Pond P and Lewis J (2019) Riots and Twitter: connective politics, social media and framing discourses in the digital public sphere. Information, Communication \& Society 22, 213-231.

Saunders C (2008) Double-edged swords? Collective identity and solidarity in the environment movement. The British Journal of Sociology 59, 227-253.

Shesterinina A (2016) Collective threat framing and mobilization in civil War. American Political Science Review 110, 411-427.

Snow D (2001) Collective Identity and Expressive Forms. University of California, Irvine eScholarship Repository. Retrieved 15 July 2020 http://repositories.cdlib.org/csd/01-07.

Snow D and Benford RD (1988) Ideology, frame resonance and participant mobilization. In Klandermans B, Kriesi H and Tarrow S (eds), International Social Movement Research. Greenwich: JAI Press, pp. 197-217.

Snow D and Corrigall-Brown C (2015) Collective identity. In Wright JD (ed.), International Encyclopedia of the Social \& Behavioral Sciences. Oxford: Elsevier, pp. 174-180.

Snow D and McAdam D (2000) Identity work processes in the context of social movements: clarifying the identity/movement nexus. In Stryker S, Owens TJ and White RW (eds), Self, Identity, and Social Movements. Minneapolis: University of Minnesota Press, pp. 41-67.

Snow D, Cress D, Downey L and Jones A (1998) Disrupting the 'quotidian', reconceptualizing the relationship between breakdown and the emergence of collective action. Mobilization: An International Quarterly 3, 1-22.

Stryker S (1980) Symbolic Interactionism: A Social Structural Version. Menlo Park: Benjamin-Cummings. 
Tajfel H (1978) Differentiation Between Social Groups: Studies in the Social Psychology of Intergroup Relations. London: Academic Press.

Tajfel H and Turner J (1986) The social identity theory of intergroup behavior. In Worchel S and Austin WG (eds), Psychology of Intergroup Relations. Chicago: Nelson-Hall, pp. 7-24.

Tarrow S (2011) Power in Movement: Social Movements and Contentious Politics. Cambridge: Cambridge University Press.

Taylor C (1989) Sources of the Self: The Making of the Modern Identity. Cambridge: Harvard University Press.

Tilly C (2004) Social boundary mechanisms. Philosophy of the Social Sciences 34, 211-236.

Turner JC (1999) Some current issues in research on social identity and self-categorization theories. In Ellemers N, Spears R and Dossje B (eds), Social Identity: Context, Commitment, Content. Oxford: Blackwell, pp. 6-34.

Turner JC, Hogg MA, Oakes PJ, Reicher SD and Wetherell MS (1987) Rediscovering the Social Group: A Self-Categorization Theory. Oxford: Basil Blackwell.

Yuen S (2018) Contesting middle-class civility: place-based collective identity in Hong Kong's Occupy Mongkok. Social Movement Studies 17(4), 393-407.

Yuen S and Cheng EW (2020) Between high autonomy and sovereign control in a subnational island jurisdiction: The paradox of Hong Kong under 'One Country. Two Systems'. Island Studies Journal 15, 131-150.

Cite this article: Yuen S, Tong K-L (2021). Solidarity in diversity: online petitions and collective identity in Hong Kong's Anti-Extradition Bill Movement. Japanese Journal of Political Science 22, 215-232. https://doi.org/10.1017/ S146810992100030X 